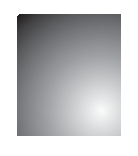

\title{
Does Foreign Direct Investment Cause Higher Levels of Productivity or do Higher Levels of Productivity Attract Foreign Direct Investment? A Study in Transforming Brazilian IndUSTRY
}

\author{
Investimento Direto Estrangeiro Causa Níveis Mais Elevados de \\ Produtividade ou Níveis Elevados de Produtividade Atraem Mais \\ Investimento Direto Estrangeiro? Um Estudo na Indústria de \\ Transformação Brasileira
}

\author{
Nádia Campos Pereira \\ Professora do Departamento de Administração, Universidade Federal de Goiás - Catalão - GO, Brasil. \\ E-mail: nadiacpereira@yahoo.com.br \\ Cristina Lelis Leal Calegario \\ Professora do Departamento de Administração e Economia, Universidade Federal de Lavras - Lavras - MG, Brasil. \\ E-mail: ccalegario@dae.ufla.br \\ Ricardo Pereira Reis \\ Professor do Departamento de Administração e Economia, Universidade Federal de Lavras - Lavras - MG, Brasil. \\ E-mail: ricpreis@ufla.br
}

\section{Abstract}

With this research we aimed to investigate the factors that determine the investment decision of foreign investors in the Brazilian industry. Evidence shows that foreign investors are attracted not only by more productive and best performing sectors, but depending on the adopted strategy, they may choose investment projects in sectors that have lower performance levels and offer potential of growth and the improvement of efficiency levels. Granger causality test indicated that not only foreign investment generate productivity gains, but also productivity induces more foreign investment inputs. Foreign investors are also attracted by those sectors using their assets inefficiently that offer potencial to generate profits. These sectors may be attractive to investors seeking a more aggressive growth policy in order to get advantages on the availability of inefficiently used assets. These sectors may be also attractive targets to investors who seek to compete directly in relatively less competitive sectors.

Key words: Investment Decision. Foreign Investors. Transforming Brazilian Industry.

\section{Resumo}

Com esta pesquisa, objetivou-se investigar os fatores que determinam a decisão de investimento de investidores estrangeiros na indústria de transformação brasileira. Os resultados indicam que investidores estrangeiros são atraídos não somente por setores com maiores níveis de desempenho, mas também por setores com menores níveis de desempenho, mas que ofereçam potencial de crescimento e níveis de eficiência. O teste de causalidade confirmou a hipótese de que não somente o investimento estrangeiro gera maiores ganhos de produtividade, mas também a produtividade induz a maiores ingressos de investimento estrangeiro. Setores que utilizam de forma ineficiente seus ativos podem ser atraentes para investidores que buscam investir em uma política de crescimento mais agressiva e obter vantagens sobre ativos utilizados de forma ineficiente. Esses setores podem ser alvo de investidores que buscam competir diretamente em setores relativamente menos competitivos.

Palavras-chave: Investimento Direto Estrangeiro. Produtividade. Indústria de Transformação Brasileira. 


\section{INTRODUCTION}

In recent years, researchers around the world have sought to develop a theory that could explain the factors that determine the investment decision of foreign investors in countries different from their original ones. They search the motivations that lead investors to develop their activities in another country by means of foreign direct investment (FDI).

The theory so far developed on the determinant factors on the investment decision of foreign investors points out that the international capital movements are rather complex, and they are related not only to the competitive environmental organization but also to the economic characteristics of the origin and the host FDI countries.

Theory on determinant FDI factors points out that foreign investors invest in foreign production basically for three reasons. The first one concerns the obtaining of raw materials in order to acquire manufactured products, which will be used in their enterprises in the host country; they intend also to penetrate local markets. (FREUND; DJANKOV, 2000)

Tendencies show that companies acquire some others or merge with others in order to be stronger in some production or market areas. According to Dunning (1997), this means that decisions in a multinational company on what to produce, where to extract inputs from, and who to sell to are based not only in the local attractiveness of a country compared to other ones, but also on what is perceived as a way to advance the corporate company's global market interest instead of the interest of a foreign subsidiary or group of subsidiaries. If the country of origin wants to get benefits from this investment, the host country governments need to formulate and implement macroeconomic strategies to compete for the same resources and markets.

This movement raises several questions and expectative concerns relative to the strategy used by foreign investors and their contribution to developing countries' economic improvement.

Information obtained from the FDI determinant factors model may be useful to public policy managers, students, business managers, investors, lawyers and accountants interested in this question in order that they can better understand the effects of inputs by foreign investment in host economies. For example, public policy managers who have an interest in competition levels, industry concentration rates and on prices paid by customers may use this information to develop policies and strategies; students may understand better fusion and acquisition (F\&A) activities and offer independent advisories to public and private sectors. (ADELAJA et al., 1999)

For this reason, the aim of this study was to understand the reasons which determine the investment decision of foreign investors in the Brazilian. Specific aims were to investigate in a deeper way the country's characteristics that contribute to make them a foreign investors' target. The research results may give information to managers involved in the public policy formulation process and decision-making concerning external investment licensing and its localization in the country, for example.

Better understanding factors that determine inputs of foreign investments in economic activities of transforming Brazilian industry may provide empirical evidence to sustain results found in studies on the effects of theses investments. It is not clear if foreign property generates better performance or if more productive sectors simply attract more FDI.

If foreign investors choose more productive sectors to invest in, the positive correlation between foreign presence and sector productivity may be wrongly understood as a FDI positive effect.

\section{Main Theoretical Approaches on Foreign Direct InVestment (FDI)}

Foreign direct investment (FDI) represents international capital flux by which a company established in a country creates or expands a subsidiary in another one. (KRUGMAN; OBSTFELD, 2005)

More broadly, there are three agents in the FDI world. The first one is the original capital country, the second one is the external investor, and the third one is the host country that can promote FDI in order to get access to advanced technology or to new management techniques, or to increasing employment levels or new market competition.

According to Appleyard and Field (2001), the capital international movements may be classified in direct and portfolio investments. They affirm that FDI 
is associated to transnational corporations that have activity possession or control in two or more countries. As a peculiar characteristic, this investment involves not only resource transference but also property control, which imply transference of a significant part of decision power from the international company to the domestic investors. The investments that do not involve property control are named portfolio investments, in which characteristics are received loans and financing for investment or shareholding purchase.

The first studies on a specific theory of international capital movement were done only after 1960 . From this period, many schools have contributed with literature on FDI.

International Trade economists were the first ones to consider international production as a substitute to exports. However, only after the studies of Corden (1974) and Hirsch (1976) the International trade theory began to show approaches that effectively sought to explain FDI.

Corden (1974) used the Heckcher-Ohlin-Samuelson (HOS) model to explain FDI in an international trade neoclassical perspective. This model derives from the Heckscher-Ohlin ( $\mathrm{HO}$ ) basic model, which identifies the differences in factor donation as a cause of international trade. Heckscher and Ohlin point out the importance of other factor availability, as land and capital in determining a pattern to trade from one country to another. The HO model suggests that each country will export the goods that use more intensively the most internally abundant productive factors.

However, due to small capacity for the model's empirical verification, it raised Stolper Samuelson's approach in order to complement the $\mathrm{HO}$ one, by means of Hecksher-Ohlin-Samuelson (HOS) model. It proposed analyzing effects of international trade on employment and income distribution. According to this approach, inter-sector reallocation resources determined the equilibrium to welfare in international commerce.

Corden (1974) analyzes the relation between a company's internationalizing decision based on the following premises: (a) neoclassical production functions and demand conditions are valid to all the countries, and the production is done by means of allocating production factors, work and capital; (b) human capital as well as machines and equipment are considered as mobile factors; (c) production functions and factors allocation are considered as constant in time; (d) production functions are characterized as scale constant incomes; (e) barriers and state restrictions do not influence investment location decision; (f) there are no transport costs; (g) production functions are similar to every product everywhere; (h) the only factor that presents no mobility is the work factor. The countries in possession of factors that do not show mobility among nations would automatically attract factors that are internally mobile. Although offering important contributions, this approach does not explain the FDI occurrence to countries with the same production factors, allocation and development level.

Hirsch (1976) also begins from the HOS model to evaluate a company's specific advantages. However, this author demonstrated that the HOS model was inconsistent with company internationalizing decisions. Hisrch's model sought to answer two main questions: when and in which circumstances a company takes the decision to serve international markets. His main contribution is HOS model expansion that now considers specific competing advantages to the company as well production, communications and transaction costs. Hirsch's model considers that there would be only opportunity for FDI if there were differential rates. In this case, portfolio investments and international credit would prevail. The advantage of this approach is to consider comparative analysis on different internationalizing strategies as an essential requirement to international investment theory.

In spite of showing an evolution to Corden's study (1974), the study fails to explain the IDE flux movements. After Corden (1974) and Hirsch (1976), several new theoretical approaches have emerged in order to explain determinant factors on companies internationalizing decisions, such as Vernon's Product Cycle Theory, the Industrial Organization, Dunning's Eclectical Paradigm and Institution Approach ones.

The Product Cycle Theory proposed by Vernon (1966) departed from comparative advantage assumption to explain FDI decisions as one of the possible strategies to accomplish external markets. According to this approach, the product has a lifecycle that may be classified into three stages: innovation, maturity and obsolescence. The author explains transnational companies' investment dynamic after exploring original 
countries' opportunities and the decision to export their technology to other countries, restarting the entire profit cycle. According to Vernon (1966), technological leadership means the product cycle core in international markets and technological innovations are the main determinant factors of international trade structure and product allocation in different countries.

Transnational corporations increasingly lead to new investigation lines, which are less focused in determining the optimal capital stocking and seeks more to know how this capital stock is distributed in productive operations between countries. In this context, Industrial Organization (IO) theory stands as a paradigm shift related to FDI determinant approach. It sought to build a theoretical and conceptual framework on evaluating conditions under which some markets are dominated by foreign subsidiaries and are not supplied by their own local companies or by importation.

IO is based on traditional microeconomic models. The main differential on this theory is that it analyzes ideal company and market models, which show a high abstraction and formality level. Moreover, IO introduces empirical studies on market and company structures and their interactions. This is a deeper approach on company behavior and performance. (CARLTON; PERLOFF, 2000)

Main IO theory currents are represented by Hymer's model and by Internationalizing Theory. Hymer (1976) was the first Canadian author who had indeed proposed a theory on FDI in his thesis published in 1976, which introduced FDI to IO context. According to him, transnational corporation is seen as an institution more devoted to international production than to international commerce. Hymer's starting point was the observation that local companies take advantage of the local market transnational corporations due to the best local environmental knowledge. To compete with local companies, transnational corporations should have some advantages, which could offset disadvantages of operating in a foreign environment.

Several years after Hymer's theory, another one called Internationalizing Theory was raised. Its focus was mainly microeconomic, and it represented an evolution in FDI theory. This theory's great differential is to consider the existence of transaction and externality costs. This starting point was the concept of market's imperfect operation, and it tried to explain why some intermediary international production activities were performed by means of hierarchies and not by market strength. This current takes as main references the findings of Buckley and Casson (1976) and Dunning (1997; 2000).

The earlier contributions to Internationalizing Theory came from Buckley and Casson (1976), which saw the enterprise as an amount of resources that can be allocated into product groups and into markets. According to these authors, market imperfections were exogenous to transnational corporations at the beginning and internationalizing was a kind of reaction to these market imperfections so that the company could internationalize a specific advantage whose aim was to establish a new market where previously there was a domestic one.

Eclectic Theory has a direct relationship with Internationalizing one whose starting point was IO and Location Theory joint use. Dunning $(1997 ; 2000)$ is the main representative of this theory. He proposes an integrated formulation of several FDI conditioning factors.

Dunning's model was first called Company Internationalizing Eclectic Theory, and later it was redefined as Company International Production Eclectic Paradigm (or OLI - Ownership, Location and Internalization). It shows some comments on product cycle theory on Internationalizing one, telling that they give only partial explanation to production internationalizing phenomenon.

The model departs on the assumption that there are some market failures, which could lead the company to use FDI instead of licensing or exportation as way to enter the external market. This transnational corporation model analysis of activity determinants is based on three factors: ownership, location and internalization.

Advantages of ownership involve competitive possibilities to be engaged in international activity that may have either a structural or transactional nature. Structural nature advantages derive from specific assets ownership such as patents, technological and management abilities, scale economy, human resources and so on.

Location advantages involve an assembly of complementary assets of some counties or regions, such as natural resources, infrastructure, market shape and structure, advantages related to governmental policy 
and institutional, politic, juridical and cultural environment, which stimulate transnational corporations to be engaged in direct investment processes.

Internalization sub paradigm shows a structure to evaluate alternative forms by which the companies may organize creation and exploitation of their main competences. Considering local attractions of different countries or regions, it assesses the tendency of companies that hold particular advantages of combining them with external assets of the host country by means of FDI. (DUNNING, 2000)

Dunning $(1997,2000)$ extended the eclectic paradigm application in order to better understand the reasons that lead the company to decide to produce in international markets. According to him, one of those reasons would be seeking specific resources not available in the original market, such as natural resources, materials, and cheap labor force, among others. Dunning called this kind of investment strategy as factor-seeking.

Strategies targeted to accomplish internal market demands of FDI host countries were named as market-seeking. According to Dunning (2000), companies classified under this kind of strategy invest in a country with the aim of offering goods and services to that market. The possibility of market improvement is one of the main reasons for this kind of investment.

The other type of investment strategy called efficiency seeking refers to those investments made by companies that can sell their goods around the entire world and are seeking places where production costs are reduced. This enterprise strategy is based on productive efficiency, in wich investors seek to rationalize and specialize their activities in order to get profits from the presence of scale economies as well as scope and risk diversification of geographically dispersed production activities.

Strategic-asset-seeking has, as a main characteristic, to acquire resources and assets which investor companies believe are able to support or to improve their competiveness in local and global markets. Companies classified in this kind of strategy generally get assets from external corporations in order to support or to improve their competiveness in external market and/or to weaken competitors, for example, by means of installing a new manufacturing plant, fusions, acquisitions, or joint venture operations. The goal is to ensure the realization of synergies with the set of strategic assets already existent by means of a common ownership structure to act in regional or global markets.

\section{Methodological Procedures}

The methodological purpose of this study was built based on existent theories on foreign direct investment (FDI) determinant factors, and it consisted of answering the following questions:

a) Which factors determine FDI entry in economic activity sectors of developing countries?

b) What is the relationship between FDI entries and productivity of economic activity sectors?

FDI flux movements are extremely complex and they obey a lot of factors related to the competitive environment that companies operate in, as well as the industries they are involved in and the economic factors of the investment receptor country.

Theory on FDI determinant factors suggest that investor decisions are based on specific characteristics of their economic sectors' activities as well those of the host countries. Characteristics of activity sectors, such as the size and the rhythm of productivity and exportation increasing, workers qualification and economic activity sectors performance) and also the characteristics of the investment host country, such as economic stability, capital cost and country risk, have an effect on FDI.

Studies on FDI determinants address several factors as host countries' FDI entry determinants. Based on these studies, one selected those variables often cited in literature.

Two groups compose variable matrix: the micro and the macro economical variables. The first group is composed of sector specific variables such as a) productivity; b) qualification; c) exportations; and d) rate of return on assets. The second group is composed of country specific variables such as e) capital costs; f) economical instability; and g) Brazil Risk.

The dependent variable named foreign presence will be represented by FDI fluxes received by the economical activity sector from 2000 to 2005 . FDI determinant factors theory points that capital international 
movements are quite complex and tied not only to the competitive environment the companies act in but also to the economic characteristics of FDI host countries.

Economic activity sectors productivity is represented by the industry transformation value based on the difference between gross value of industrial production and industry operation costs. Productivity indices measure rates of return on local company productive activities provided to owners and investors. High productivity levels are the focus of attention of most investors, especially those oriented to efficiency-seeking strategies. (DUNNING, 2000)

In this study, qualification variable is represented by the value of total gross wages paid by the sector related to the number of employed persons. Most qualified sectors are attractive targets to investors, especially those motivated by strategies named as strategic-asset-seeking that look for strategic assets not available in their origin countries (DUNNING, 2000). Qualification level in a specific industry is essential to get benefits from knowledge interchange. Workers' learning capacity is considered as a strategic resource, which determines FDI attraction. They are important in order to provide knowledge and synergy exchange by means of common property structure.

Exportation variable is measured by total exports of industrial sectors value. An Export database was built by External Trade Secretary, and it was obtained from information given by Developing, Industry and Commerce Ministry - MDIC (2008). Foreign investors motivated by efficiency-seeking strategy, who seek productive structure rationalization and specialization, are attracted by export sectors since they generally show higher performance levels for those efforts to reduce production costs and to get benefits from production scales and be more competitive in international markets.

Export sectors may also be attractive targets to investors motivated by strategic-asset-seeking strategy who look for assets not available in their countries. Export sectors are often forced to develop new competences such as establishment of new relationships and insertion in international distribution nets, or settling transport infrastructure beyond national boundaries, considered as attracting targets to foreign investors.

Proxy variable on rate of return on assets is represented by the selling operation value related to their total assets. Rate of return on assets represents profit generation potential, that means how much liquid profit the sector had related to investments on total assets. Sectors that show high levels of return on assets may indicate that the investments done on assets have been efficiently used in order to generate selling improvement. (CALEGÁRIO, 2005)

Capital cost will be represented by domestic interest rates, which in this study is SELIC. Interest rate is one of the variables that explain FDI entries. The greater the rate for the rest of the world, the greater is the stimulus to the application of resources in a given country (GREMAUD et al., 2002). An inverse relationship between capital costs and FDI entries indicates that an increase in interest rates implies an increased capital cost and discourages foreign investors to establish their productive activities in the country.

According to Lima Júnior (2005), proxy variable on the country's economic instability will be inflation measured by National Consumer Price Index (IPCA) given from Brazilian Geografic and Statistic Institute (IBGE). The theory on FDI determinant factors suggests that foreign investors prefer to invest in economies that show reduced inflation, that is, more stable economies with less risks.

Proxy variable chosen to represent Brazil Risk is C-Bond Index, which is calculated in database and published by Valor Econômico newspaper. That is the main title of Brazilian external debt traded in international markets, and measures the international market confidence in a country's capacity to pay its external commitments. (LIMA JÚNIOR, 2005) FDI determinant factors suggest that the greater the demand for paper, the greater its market value and the higher is investor confidence in the host country's economy.

Series used in this study analysis have data panel form, containing annual data aggregated by sector of economic activity, as defined by Economic Activities National Code (CNAE), from 2000 to 2005.

Brazilian Central Bank (BACEN) supplied data on FDI entries distributed by economic activity.

Variables named as industrial transforming value, industrial production gross value, industrial operation costs, total fixed assets, number of employed people, amount of wages paid and total operating revenue of sales, aggregated according to CNAE economic activity 
of the sector were obtained from IBGE (2005) concerning to researches from 2000 to 2005.

Data on industrial sector Brazilian exportations, classified according to technologic intensity of economic sector's activity were collected from MDIC (2008).

The SELIC interest rate, the National Index of Broad Consumer Prices (IPCA) and the C-Bond Brazilian foreign debt title were collected in IPEA website (2008) concerning to the period from 2000 to 2005. Not all sectors have submitted data for all years. In such cases, the observation was omitted from the sample.

\subsection{Generalized Linear Models}

Using General Linear Model Statistic Method (GLM), an empirical analysis model on FDI determinant factors was estimated based on the main factors commonly cited in literature as those determinant factors on FDI entry in developing countries economies.

Linear equation models may be expressed as a dependent variable in function of an assembly of independent ones represented by the following equation:

$$
Y=a+b X_{i t}+e_{i t}
$$

where $\mathrm{Y}$ represents the FDI flux received by $\mathrm{i}$ sector in a period $t ; a_{i}$ the intercept; $b$ the parameters to be estimated; $X_{i t}$ the matrix of explicative variables composted by k regresses without the constant; and $e_{i}$, the random $Y$ error to the $i$.

Generalized linear models, or MLG, are an extension of traditional linear regression models, and they were proposed earlier by Nelder and Wedderburn (1972). These authors have demonstrated that techniques that were previously treated in isolation could be grouped using other types of distributions belonging to the "exponential family".

Moreover, while in classical linear regression models the relationship between the average value of the response variable and the linear combination is a function of identity, in MLG this relationship can be established by any monotonic function and differential.

MLG was developed in order to estimate regression models where the assumption of variance homogeneity were violated or when errors did not show a normal distribution. Nelder and Wedderburn (1972) showed that most of the statistical problems that arise in several areas of scientific knowledge could be formulated in a unified manner as regression models.

While the classic linear model supposes normality, addictiveness and constant variance, MLG seeks to treat them in an independent way. The advantages of using these models lie in the fact that they consider distributions other than normal and, moreover, do not require constant variance; linearity can be obtained through a function that makes the connection between the average response variable and polynomial linear independent variables.

These models involve a non-variable response variable, explanatory variables and a random sample of observations, and the response variable, or random component of the model, has a distribution that belongs to the exponential family in canonical form. Moreover, the explanatory variables come in the form of a linear model (systematic component) and the connection between random and systematic components is made through a link function. (DEMÉTRIO, 2002)

Thus, any generalized linear model can be defined by three components: a random component, a systematic one and a liaison function. (McCULLAGH; NELDER, 1989)

The random component, or variable distribution response component, is a member of probability distribution exponential family and is also known as structure of errors. In this component, it is considered $N$ the random variables $Y_{i}(i=1, \ldots, N)$, independent of medium $m_{i}$, and a probability function belonging to the exponential family, i.e.:

$$
f\left(y_{i} / \theta_{i}, \phi\right)=\exp +\left\{\frac{y_{i}-b\left(\theta_{i}\right)}{a_{i}(\phi)}=c\left(y_{i}, \phi\right)\right\}
$$

The systematic component consists in a vector of explicative variables $x_{1}, x_{2}, \ldots, x_{n}$ another parameter vector $b_{(p \times 1)}$, which will be estimated with data and both form a linear predictor $h=\left(h_{1}, \ldots h_{n}\right)$, i.e., the amount of independent variables that describe the model linear structure by means of the formula.

$$
\eta_{j}=\sum_{j=1}^{p} x_{i} \beta_{j}
$$

where $b_{j}, j=1, \ldots p$ constitute an unknown parameter to be estimated from the data.

The link function relates the random component of the model to the systematic one, i.e., linking the 
linear predictor to the natural average of the answer variable.

This function has to be monotonous and differentiable, whose relationship can be expressed by:

$$
\eta_{i}=g\left(\mu_{i}\right)
$$

where $i=1,2,3, \ldots, n$ and $m=\left(m_{1}, \ldots, m_{n}\right)$ represents the vector of aleatory variable average $y_{i}(i=1, \ldots n) e$ $E\left(y_{i}\right)=m_{i}$.

\section{Results and Analysis}

The first step of the empirical analysis consisted of analyzing the correlation between the selected variables to compose de FDI determinant factors model. The method used to measure the degree of association between the variables in this study was Pearson's correlation coefficient. Highly related variables may cause multicollinearity problems, which is not desirable. The results for the Pearson test correlation are shown in Table 1.

Table 1: Pearson correlation test for variables of FDI determinant factors model

\begin{tabular}{|c|c|c|c|c|c|c|c|}
\hline \multicolumn{2}{|r|}{2} & 3 & 4 & 5 & 6 & 7 & 8 \\
\hline \multirow{2}{*}{$1^{\mathrm{a}}$} & \multirow{2}{*}{1,0000} & 0,1867 & $-0,3783$ & $-0,0657$ & 0,0308 & $-0,0240$ & $-0,0698$ \\
\hline & & 0,0764 & 0,0002 & 0,5357 & 0,7717 & 0,8213 & 0,5104 \\
\hline \multirow{2}{*}{$2^{\mathrm{b}}$} & & \multirow{2}{*}{1,0000} & 0,1238 & 0,0852 & 0,0810 & $-0,0229$ & $-0,1187$ \\
\hline & & & 0,2421 & 0,4216 & 0,4450 & 0,8293 & 0,2623 \\
\hline \multirow{2}{*}{$3^{c}$} & & & 1 & 0,0891 & $-0,0284$ & $-0,0935$ & $-0,1430$ \\
\hline & & & & 0,4006 & 0,7889 & 0,3778 & 0,1762 \\
\hline \multirow{2}{*}{$4^{d}$} & & & & & 0,06669 & $-0,0966$ & $-0,3015$ \\
\hline & & & & 1,0000 & 0,5299 & 0,3619 & 0,0037 \\
\hline \multirow{2}{*}{$5^{e}$} & & & & & $1 \rho 0 \Omega 0$ & 0,5781 & 0,3172 \\
\hline & & & & & 1,0000 & $<, 0001$ & 0,0022 \\
\hline \multirow{2}{*}{$6^{f}$} & & & & & & 10000 & 0,6965 \\
\hline & & & & & & 1,0000 & $<, 0001$ \\
\hline $7^{\mathrm{s}}$ & & & & & & & 1,0000 \\
\hline
\end{tabular}

aproductivity; ${ }^{\mathrm{b}}$ qualification; ' $\mathrm{cexportations;}{ }^{\mathrm{d}}$ rate of return on assets; ${ }^{\mathrm{e}}$ capital cost; 'economic instability; "Brazil Risk.

Source: Research results (2008)

It is noteworthy that among the variables selected to compose the complete model, economic instabi- lity and Brazil risk presented themselves correlated, suggesting the possibility of problems associated with multicollinearity of data. However, as these are important variables in the model, we chose initially to keep the variables, since they do not harm the model selected for analysis. As these variables are essential to estimate the model of the FDI determinants, it could not simply exclude these variables in models. The solution found was to use the tolerance (TOL) and the factor variance inflation (FVI) as a complementary measure to detect multicollinearity. The main objective of these measures is to verify the degree in which each independent variable is explained by other independent variables. They are commonly used as a multicollinearity indicator. Very small tolerance values and, consequently, FVI great values denote high collinearity (GUJARATI, 2006).

As the results for these statistics are in accepted limits, one can discard the possibility of multicollinearity problems associated with the data (Table 2). Therefore, we chose to keep these variables in the model.

Table 2: Multicollinearity diagnosis for FDI determinant factors model

\begin{tabular}{|l|c|c|c|}
\hline \multicolumn{1}{|c|}{ VARIABLE } & $\begin{array}{c}\text { FreedoM } \\
\text { DeGREE }\end{array}$ & TOLERANCE & $\begin{array}{c}\text { VARIANCE INFLATION } \\
\text { FACTOR }\end{array}$ \\
\hline LNPROD & 1 & 0,83523 & 1,19728 \\
\hline LNQUAL & 1 & 0,9309 & 1,07422 \\
\hline LNEXP & 1 & 0,81372 & 1,22892 \\
\hline LNIROA & 1 & 0,83383 & 1,19928 \\
\hline CUSTOCAP & 1 & 0,38758 & 2,58011 \\
\hline INSTECO & 1 & 0,13714 & 7,29158 \\
\hline RISCO & 1 & 0,19912 & 5,022 \\
\hline
\end{tabular}

Source: Research results (2008)

After data multicollinearity analysis, a graphical analysis of the residuals was used in order to test the hypothesis of autocorrelation presence in terms of the error. A graph of predicted values in relation to deviance residuals was built. The results presented in Figure 1 demonstrate no predicted trend pattern in the predicted observations in relation to deviations residuals, indicating that there is no evidence of autocorrelation in terms of the error. Denied the hypothesis of problems associated with data multicollinearity and autocorrelation in terms of error, the analysis of FDI determinants model was conducted. 
The next step consisted in the fit models analysis. This analysis was based on deviations presented in Table 3. The fit of models analysis in MLG is based on the deviance statistics. Allison (2001) do not recommend treating deviations in isolation but comparing them with those of other models. In general, the lower the value of deviations, the better the fit of the model to data.

Based on the results, we can affirm that the full model that incorporates both the variables of individual characteristics of sectors of economic activity as the variables of country characteristics, showed a better fit compared to other models. Among the analyzed models, the full model demonstrated statistically significant and has the lowest value of the deviations.

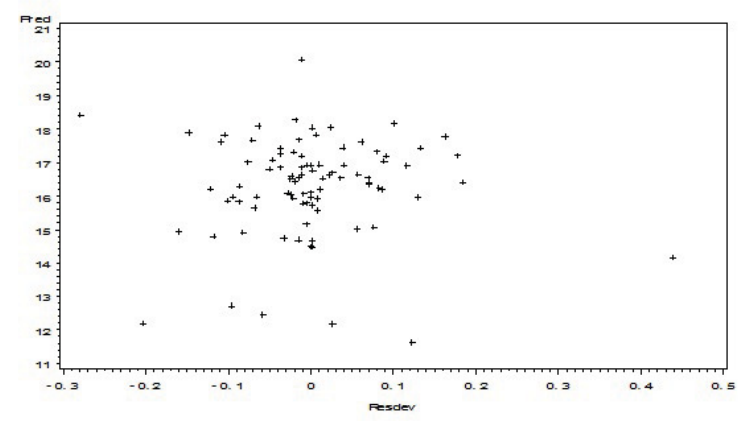

Figure 1: Predicted values in relation to deviance residuals for FDI determinant factors model Source: Research results (2008)

The results for the model containing all variables under study, in other words, the variables related to the specific characteristics of the sector and the country, are presented in Table 4. They indicate that the variable productivity (LNPROD) was statistically significant at $1 \%$ and positively related to the dependent variable under study, in order of 0.1657 . The same occurred with qualification (LNQUAL) that showed having a direct relationship on the order of 0.1337 and statistically significant at 5\% (Table 4). Among the models tested, the full model demonstrated statistically significant and has the lowest value deviations.

It is observed that foreign investors tend to be attracted to more productive and skilled sectors of economic activity. More productive sectors are generally attractive to foreigner investors seeking for greater productive efficiency strategies, and therefore, seeking for sectors with potential for rationalizing its operations and adding expertise to its subsidiaries. Sectors most qualified are considered attractive targets for investors seeking resources and strategic assets not available in the country of origin. The level of training and learning ability of workers in a sector are considered important strategic resources that determine FDI attraction. They are important for the exchange of expertise and synergy through ownership structures in common.

Table 3: Variance Analysis to FDI determinant models

\begin{tabular}{|c|c|c|c|c|}
\hline VARIANCE & 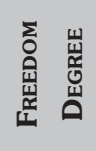 & 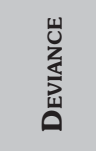 & 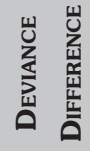 & $\mathbf{F}_{0}$ \\
\hline $\mathrm{X} 1$ & 87 & 3,2084 & - & - \\
\hline $\mathrm{X} 1, \mathrm{X} 2$ & 86 & 3,0201 & 0,1883 & $5,0473^{* * *}$ \\
\hline $\mathrm{X} 1, \mathrm{X} 2, \mathrm{X} 3$ & 85 & 2,9470 & 0,0731 & 2,0574 \\
\hline $\mathrm{X} 1, \mathrm{X} 2, \mathrm{X} 3, \mathrm{X} 4$ & 84 & 2,8483 & 0,0987 & $2,8133^{*}$ \\
\hline $\mathrm{X} 1, \mathrm{X} 2, \mathrm{X} 3, \mathrm{X} 4, \mathrm{X} 5$ & 83 & 2,8110 & 0,0373 & 1,0869 \\
\hline $\mathrm{X} 1, \mathrm{X} 2, \mathrm{X} 3, \mathrm{X} 4, \mathrm{X} 5, \mathrm{X} 6$ & 82 & 2,7688 & 0,0422 & 1,2310 \\
\hline $\begin{array}{l}\mathrm{X} 1, \mathrm{X} 2, \mathrm{X} 3, \mathrm{X} 4 \\
\mathrm{X} 5, \mathrm{X} 6, \mathrm{X} 7\end{array}$ & 81 & 2,3909 & 0,3779 & $11,0553 * * *$ \\
\hline
\end{tabular}

$\mathrm{X} 1, \mathrm{X} 2, \mathrm{X} 3, \mathrm{X} 4, \mathrm{X} 5, \mathrm{X} 6$ and $\mathrm{X} 7$ variables represent, respectively: productivity, qualification, exportations, rate of return on assets, capital costs, economic instability and Brazil Risk.

*** Significant, to $1 \%$; ** significant, to $5 \%$; * significant, to $10 \%$.

Source: Research results (2008)

The exports (LNEXP) variable was not significant in this study (Table 4). The results can be attributed to the fact that the decision of foreign investment is closely related to its strategy in the FDI host country. For example, if investors seek to operate specific features not available in the original market, such as natural resources, raw materials and cheap labor, then the investment decision will focus on these resources' availability in the industry much more than their export levels in the sector.

The same can occur if investors are advised to supply the domestic market of the recipient countries of FDI. The goal of investors in this kind of approach is to offer goods and services to the market, and the possibility of market growth is the main determinant of investment decisions. For investors engaged in this type of strategy, factors such as size and market growth, as well as the preference of consumers, tend to be more important (DUNNING, 2000). In fact, this strategy reflects exactly what happened in Brazil. FDI came to 
appropriate from internal market, not contributing to an improvement in Brazilian trade balance. According to Fernandes (2006), this strategy involves a small exchange of goods, since it presents low propensity to export and import. One concern about FDI entries refers to the fact that deficit and with lowest expression in exports and imports sectors are the ones that have received more flows of FDI.

Table 4: Results for FDI determinant factors model

\begin{tabular}{|c|c|c|c|c|c|}
\hline \multirow{2}{*}{$\begin{array}{c}\text { Parameters } \\
\text { INTERCEPTO }\end{array}$} & \multicolumn{2}{|c|}{ EstimATI- STANDARD } & \multicolumn{2}{|c|}{$\begin{array}{c}\text { WaLD Confidence } \\
\text { Limits (95\%) }\end{array}$} & \multirow{2}{*}{$\begin{array}{c}\text { CHI- } \\
\text {-SQUARE } \\
4,51^{* *}\end{array}$} \\
\hline & $-1,3471$ & 0,6341 & $-2,5899$ & $-0,1043$ & \\
\hline LNPROD & 0,1657 & 0,0149 & 0,1366 & 0,1948 & $124,57^{* * *}$ \\
\hline LNQUAL & 0,1337 & 0,0441 & 0,0473 & 0,2202 & $9,20 * *$ \\
\hline LNEXP & $-0,0179$ & 0,0124 & $-0,0423$ & 0,0064 & 2,08 \\
\hline LNIROA & $-0,0041$ & 0,0025 & $-0,0089$ & 0,0007 & $2,75^{* *}$ \\
\hline CUSTOCAP & $-0,1214$ & 0,0567 & $-0,2325$ & $-0,0103$ & $4,59 * *$ \\
\hline INSTECO & 0,0084 & 0,0175 & $-0,0259$ & 0,0426 & 0,23 \\
\hline RISCO & 0,0092 & 0,0907 & $-0,1685$ & 0,1869 & 0,01 \\
\hline
\end{tabular}

*** Significant, to $1 \%$; ** significant, to $5 \%$; * significant, to $10 \%$. Source: Research results (2008)

Rate of return on assets variable (LNROA) performed inversely related to the foreign presence variable (LNIDE) in the order of -0.0041 and statistically significant at $5 \%$, indicating that foreign investors tend to be attracted to industries with low rate of return on assets (Table 4). The result is the opposite of the expected and suggests that foreign investors are attracted to sectors that use assets inefficiently to generate profits. According to Calegario (2005), these sectors may become target of foreign investors who seek to use their skills and know-how to take advantage of the availability of assets used inefficiently and allows investment in a policy of aggressive growth. Moreover, these groups may become target of investors who seek to compete with industries that have lower performance levels. The entry of foreigners and specifically transnational corporation subsidiaries in these sectors may lead to a fall in the number companies if foreign ones have come to directly compete with domestic firms that are relatively less competitive and less prepared in terms of the benefits of ownership.
These results show that foreign investors are attracted more by productive sectors with higher levels of performance. Depending on the adopted strategy, they may opt for investing projects in sectors with lower levels of performance but offering potential for growth and improvements in efficiency levels. Moreover, the strategy for investors is that of resource seeking or market seeking while other factors, such as resource availability, size and market growth, are also important.

As regards the variable cost of capital (CUSTOCAP), the results indicated an inverse relationship rather to -0.1214 and statistically significant (Table 4). It is observed that foreign investors are averse to high rates of capital cost. Investors especially motivated by seeking efficiency-strategy, look for efficiency and lower production costs and therefore invest less in countries that have high capital costs.

Economic instability and Brazil Risk variables were not statistically significant in this study (Table 4). Empirical evidence on capital movements points to economic stability as an important determinant of FDI flows. According to Fernandes (2006), an explanation for that result could be that Brazil's economic stability is not an important factor in attracting FDI the same way as occurs in other countries. That's because Brazil was the only country in the world to do indexing for years, which may be masking the result. Regarding Brazil Risk, it is possible that this variable may be more important in explaining financial flows of investment or speculative investment, and FDI is insensitive to it (Table 4).

To complete the analysis, the Granger's causality test (1969) was conducted to test the causality direction between foreign presence and productivity of the sectors of economic activity.

Since Granger's causality test (1969) is based on the asymptotic distribution of the data, the variables are recommended to be integrated in the same order. To circumvent this limitation, we suggest working with differentiated variables, which can result in lower long-term information.

Considering the fact that most macroeconomic variables showed strong trends and that their means and variances vary over time, it becomes necessary to analyze the order of integration of the two series under study.

For this, we used the Expanded Dickey-Fuller test $(\mathrm{ADF})$ in order to test the presence of unit root under 
Nádia Campos Pereira • Cristina Lelis Leal Calegario • Ricardo Pereira Reis

Table 5: Dickey-Fuller Test applied to the selected variables

\begin{tabular}{|c|c|c|c|c|c|c|c|}
\hline TYPE & LAGS & RHO & Рвов $<$ RHO & $\mathbf{T}$ & РRов $<$ T & $\mathbf{F}$ & РrOB $<F$ \\
\hline \multicolumn{8}{|l|}{ Productivity } \\
\hline Zero mean ${ }^{1}$ & 0 & $-71,6278$ & $<, 0001$ & $-7,68^{4}$ & $<, 0001$ & - & - \\
\hline Single mean ${ }^{2}$ & 0 & $-87,8098$ & 0,0009 & $-9,15^{5}$ & $<, 0001$ & $41,82^{7}$ & 0,0010 \\
\hline Trend $^{3}$ & 0 & $-88,6395$ & 0,0003 & $-9,18^{6}$ & $<, 0001$ & $42,16^{8}$ & 0,0010 \\
\hline \multicolumn{8}{|c|}{ Foreign Presence } \\
\hline Zero mean & 0 & $-78,9403$ & $<, 0001$ & $-8,34$ & $<, 0001$ & - & - \\
\hline Single mean & 0 & $-93,4580$ & 0,0009 & $-9,74$ & $<, 0001$ & 47,43 & 0,0010 \\
\hline Trend & 0 & $-94,7866$ & 0,0003 & $-9,84$ & $<, 0001$ & 48,42 & 0,0010 \\
\hline
\end{tabular}

${ }^{1}$ Without constant and tendency model; ${ }^{2}$ with constant and without tendency model a; $;{ }^{3}$ with constancy model $;{ }^{4}$ statistic $;{ }^{5}$ statistic $;{ }^{6}$ statistic $;{ }^{7}$ statistic $;{ }^{8}$ statistic .

Source: Research results (2008)

the assumption that the series in question are stationary around a trend of time.

The results presented in Table 5 for the ADF test indicate that both variables have the order of integration I (0). As the values found for the statistics relating to individual and joint tests proved significant, the hypothesis of a unit root for the variables in level was rejected.

It can be said that Granger's causality test (1969) is recommended and can be applied without loss of information to analyze the causality direction between the variables foreign presence and productivity of the sectors of economic activity.

The results of these causality tests are given in Table 6. According to them, the direction of causality between foreign presence and productivity of the sectors of economic activity occurs in both directions. That is, FDI not only caused higher levels of productivity but also higher levels of productivity attract FDI.

Table 6: Granger's causality test for foreign presence and productivity variables

\begin{tabular}{l|c|c|}
\hline Variables & \multicolumn{1}{c}{ T RATIO PROB $>\mid$ T $\mid$} \\
\hline Productivity (LNPROD) $\rightarrow$ Foreign Presence (FDI) & 1,52 & 0,0001 \\
\hline Foreign Presence (FDI) $\rightarrow$ Productivity (LNPROD) & 23,72 & 0,0001 \\
\hline
\end{tabular}

Source: Research results (2008)

\section{Conclusions}

The results suggest that foreign investors tend to be attracted by more productive and skilled economic activity sectors. Sectors with lower levels of return on assets may also become a target of foreign investors who seek to use their skills and know-how to take advantage of the availability of assets used inefficiently. Furthermore, the results confirm that foreign investors are averse to high rates of capital cost.

Empirical evidence found in this study demonstrates that foreign investors are attracted not only by more productive sectors with higher levels of performance but, depending on the adopted strategy, they may opt for investment projects in sectors with lower performance levels which offer potential for growth and improvement in efficiency levels. Moreover, these groups may become a target for investors seeking less competitive industries to invest in. The result indicates that foreigners can be attracted by the opportunity to compete in less dynamic and less competitive sectors.

Granger's causality test indicated that the direction of causality between foreign presence productivity in economic activity sectors occurs in both directions, confirming that FDI not only cause higher levels of productivity but also higher levels of productivity attract FDI.

It can be observed, therefore, that although there is a causal relationship both in terms of FDI to 
productivity as in the opposite direction, the results presented for the FDI determinants model show that investors are rather attracted to industries with higher productivity levels, but they also are attracted to sectors that use assets inefficiently to generate profits. These sectors can be attractive to foreign investors seeking to invest in a more aggressive growth policy and to take advantage of the availability of assets used inefficiently. However, these sectors can also be attractive targets for investors seeking to compete directly in sectors that are relatively less competitive and less prepared in terms of the benefits of ownership.

The results of this study raise, therefore, a series of questions to be answered. Some of them are due to the limitations of the study, mainly related to the fact of using analysis from data aggregated sector levels and also due to unavailability of data. Industry data does not allow deeper analysis and detailed information about the research object but, on the other hand, enables the findings and generalizations to the universe of research.

The improvement and intensification of these studies could provide theoretical and empirical support for policy decisions related to policies or incentives to control FDI entries in the host country. The different factors involved in formulating public policies need information to provide subsidies for the training of legal and institutional instruments that relate to the regulation of foreign capital.

\section{REFERENCES}

ADELAJA, A.; NAYA JÚNIOR, R.; FAROOQ, Z. Predicting mergers and acquisitions in the food industry.

Agribusiness, New York, v. 15, n. 1, p. 1-23, 1999.

\section{ALLISON, P. D. Logistic regression using SAS}

Systems: theory and applications. 2. ed. Cary, NC: SAS Institute 2001. $280 \mathrm{p}$.

APPLEYARD, D. R.; FIELD JÚNIOR, A. J. International economics, EUA: Irwin/McGraw-Hill, 1998. 748 p.

BANCO CENTRAL DO BRASIL. Pesquisa de câmbios e capitais estrangeiros no Brasil. [2008]. Disponível em: $<$ http://www.bcb.gov.br/>. Acesso em: 2 jun. 2008.

\section{BUCKLEY, P. J.; CASSON, M. C. The future of the} multinational enterprise. London: Macmillan, 1976. $142 \mathrm{p}$.

CALEGARIO, C. L. L. Economic analysis of foreign market entry strategies in the US/EU agricultural trade context. 2005. 96 p. Tese (Doutorado em Economia Agrícola) - The University of Georgia, Athens, Georgia, 2005.

\section{CARLTON, W.; PERLOFF, J. Modern industrial}

organization. 3. ed. New York: Addison Wesley, 2000. $973 \mathrm{p}$.

DUNNING, J. H. The eclectic paradigm as an envelope for economic and business theories of MNE activity. International Business Review, Elsevier Science Pergamon, v. 9, n. 2, p. 163-190, Apr. 2000.

DUNNING, J. H. The European internal market programme and inbound foreign direct investments. Journal of Common Market Studies, Blackwell Publishers, Oxford UK, v. 35, n. 1, p. 1-30, Mar. 1997.

CORDEN, W. M. The theory of international trade. In: DUNNING, J. H. (Ed.) Economic analysis and the multinational enterprise. London: George Allen \& Unwin, 1974. 405 p.

DEMÉTRIO, C. G. B. Modelos lineares generalizados em experimentação agronômica. ESALQ/USP, 2002. 121 p. Disponível em: <http://www.lce.esalq.usp.br> Acesso em: 15 set. 2007.

\section{FERNANDES, E. A. Investimento externo direto no}

Brasil: efeitos no crescimento, nas exportações e no emprego. 2006. 143 p. Tese (Doutorado em Economia Aplicada) Universidade Federal de Viçosa, Viçosa, MG, 2006.

FREUND, C.; DJANKOV, S. Wich firms do foreigns Buy? Evidence from the Republic of Korea. Policy Research Working Paper, The world Bank, v. 1, n. 2.450, 2000. Disponível em: < http://elibrary.worldbank.org/docserver/ download/2450.pdf?expires $=1298241597 \& \mathrm{id}=\mathrm{id} \&$ accna me $=$ guest\&checksum $=$ DE6C9B6BD4BF8B8FD1B40206 FBD69AF6 > . Acesso em: 15 mar. 2007.

GRANGER, A. Investigating casual relationship by econometric models and cross spectral methods. Econometrica, New York, v. 37, n. 3, p. 424-458, Aug. 1969. 
GREMAUD, A. P.; VASCONCELLOS, A. S. de; TONETO JUNIOR, R. Economia brasileira contemporânea. 4. ed. São Paulo: Atlas, 2002. 208 p.

\section{GUJARATI, D. Econometria básica econometria}

básica. 4. ed. Rio de Janeiro: Elsevier, 2006. 819 p.

HIRSCH, S. An international trade and investment theory of the firm. Oxford Economic Papers, Oxford, v. 28, n. 2, p.258-270, July 1976.

HYMER, S. H. The international corporations of national firms: a study of direct foreign investment. 1976. 340 p. Dissertation (Master in Economics) Massachusetts Institute od Technology, Cambridge, Massachusetts MIT Cambridge, Massachusetts, 1976.

IBGE - INSTITUTO BRASILEIRO DE GEOGRAFIA E ESTATÍTICA. Pesquisa Industrial Anual, Rio de Janeiro, v. 24, n.1, p.1-275, 2005. Disponível em: <http:// www.ibge.gov.br/home/estatistica/economia/industria/pia/ empresas/defaultempresa2005.shtm >. Acesso em: 5 mar. 2013.

INSTITUTO DE PESQUISA ECONÔMICA APLICADA. Ipeadata macroeconômico. [2008]. Disponível em: <http://www.ipeadata.gov.br/>. Acesso em: 10 fev. 2008.

KRUGMAN, P.; OBSTFELD, M. Economia

internacional: teoria e política. 6. ed. São Paulo: Pearson Addison Wesley, 2005. 558 p.

LIMA JUNIOR, A. Determinantes do investimento direto estrangeiro no Brasil. 2005. 80p. Dissertação (Mestrado em Economia) - Universidade Federal de Minas Gerais, Belo Horizonte, 2005.

MCCULLAGH, P.; NELDER, J. A. Generalized linear models. New York: Chapman \& Hall, 1989. 511 p.

MINISTÉRIO DO DESENVOLVIMENTO, INDÚSTRIA E COMÉRCIO. Balança comercial dos setores de atividade econômica. [2008]. Disponível em: < http:// www.desenvolvimento.gov.br/sitio/>. Acesso em: 25 maio 2008.

NELDER, J. A.; WEDDERBURN, R. W. M. Generalized linear models. Journal of the Royal Statistical

Society, London, v. 135, n. 3, p. 370-384, Jun. 1972.
VERNON, R. International investment and international trade in the product cycle. Quarterly Journal of

Economics, The MIT Press, v. 30, p.190-207, May 1966. 